\title{
Comparison of Revised Trauma Score Based on Intracranial Haemorrhage Volume among Head Injury Patients
}

\author{
Albert Tito', Sonny G. R. Saragih ${ }^{2}$, Diana Natalia ${ }^{3}$ \\ ${ }^{1}$ Medical Education Program, Faculty of Medicine, Tanjungpura University, \\ Pontianak, Indonesia; \\ ${ }^{2}$ Department of Neurosurgery, Dr. Abdul Aziz General Hospital, Singkawang, \\ Indonesia; \\ ${ }^{3}$ Department of Parasitology, Faculty of Medicine, Tanjungpura University, \\ Pontianak, Indonesia
}

Received January 20, 2018; Accepted March 19, 2018.

Key words: Revised Trauma Score - Intracranial haemorrhage volume - Head injury - Head CT-scan

\begin{abstract}
Head injury is one of the leading causes of mortality and morbidity at all ages and may develop into intracranial haemorrhage and increasing intracranial pressure. Pre-assessment must be conducted to head injury patients to decide the treatment plan. The aim of this study was to compare Revised Trauma Score (RTS) based on intracranial haemorrhage volume among head injury patients. This study was an analytic study with cross-sectional design where 31 patients were studied. The admission RTS and patients' status data were obtained from medical records at Dr. Abdul Aziz General Hospital, Singkawang, Indonesia and intracranial haemorrhage volume data were obtained from the head CT-scan. The data were analysed by Mann-Whitney U-test. The admission Revised Trauma Score rates were significantly different $(95 \% \mathrm{Cl}, \mathrm{p}=0.006)$ by intracranial haemorrhage volume which the RTS rate of less intracranial haemorrhage volume group was $11.40 \pm 0.74$ and the RTS rate of greater intracranial haemorrhage volume group was $10.13 \pm 1.54$. The greater intracranial haemorrhage volume showed the lower RTS value which means the worse physiological condition.
\end{abstract}

Mailing Address: Dr. Albert Tito, S. Ked., Medical Education Program, Faculty of Medicine Tanjungpura University, Pontianak, 78124, West Kalimantan, Indonesia; Phone: +628 52520526 90; e-mail: albert.tito.official@gmail.com 


\section{Introduction}

Head injury is one of the leading causes of mortality and morbidity at all ages. Head injury can cause death and disability which could have permanent consequences, such as cognitive disorder, memory disorder, motor and sensory function disorder (Faul et al., 2010; Kumar and Mahapatra, 2012). Most of the head injury cases occur at the productive age, at the age of 15-24 years (AbelsonMitchell, 2013). Head injury incidence in Indonesia is relatively high as a result of traffic accidents which were $19.6 \%$ (Riyadina et al., 2009). The number of fatalities by traffic accidents in West Kalimantan were 560 people in 2013, 550 people in 2014 and 470 people in 2015 (Badan Pusat Statistik Provinsi Kalimantan Barat, 2015).

The volume of the intracranial cavity cannot change so that at a certain point, the increased intracranial haemorrhage volume is not compensated, and the intracranial pressure rises (Monro-Kellie doctrine) (Elliot and Smith, 2010). Intracranial pressure will compress and compromise brain tissue that can lead to neurological deficits, loss of consciousness, potentially leading to herniation and death (Broderick et al., 2007). Under these conditions, emergency treatment for head injury should be done quickly and accurately by using triage in the Emergency Room. To decide for the triage, an objective assessment such as Revised Trauma Score may be used (RTS). RTS is a physiological scoring system that is used to determine the severity of the injury. Parameters used to assess RTS are Glasgow Coma Scale (GCS), systolic blood pressure and respiratory rate (Table 1). RTS has a range of values from 0 to 12 with four categorizations, such as delayed if the score is 12 , urgent if the score is 11 , immediate if the score is $3-10$ and declared dead if the score is 0-3 (Rowland and Pedley, 2010; Alqarni et al., 2011; Sundstrøm et al., 2012; Orhon et al., 2014).

RTS is an assessment that can be used to determine the action in emergency cases, including head injury with intracranial haemorrhage, so the planning diagnoses and therapy could be held properly (Alqarni et al., 2011; Orhon et al., 2014). Research on the relationship between the intracranial haemorrhage volume and RTS in cases of head injury has not been frequently studied before. The

\section{Table 1 - Scoring system of Revised Trauma Score}

\begin{tabular}{lccc}
\hline GCS & Systolic blood pressure $(\mathrm{mm} \mathrm{Hg})$ & Respiratory rate (per minute) & Scoring \\
\hline $13-15$ & $>89$ & $10-29$ & 4 \\
$9-12$ & $76-89$ & $>29$ & 3 \\
$6-8$ & $50-75$ & $6-9$ & 2 \\
$4-5$ & $1-49$ & $1-5$ & 1 \\
3 & 0 & 0 & 0 \\
\hline GCS - Glasgow Coma Scale & & &
\end{tabular}


purpose of this study was to compare the value of the admission RTS based on the intracranial haemorrhage volume among head injury patients.

\section{Material and Methods}

This study used a cross-sectional design. The independent variable was intracranial haemorrhage volume with ordinal scale which was divided into two groups, such as greater and less intracranial haemorrhage volume. Greater intracranial haemorrhage volume was defined as epidural or intra-cerebral haemorrhage $\geq 30 \mathrm{ml}$ or subdural haemorrhage $\geq 10 \mathrm{~mm}$. The less intracranial haemorrhage volume was defined as epidural $(E D H)$ or intra-cerebral haemorrhage $(I C H)$ $<30 \mathrm{ml}$ or subdural haemorrhage $(\mathrm{SDH})<10 \mathrm{~mm}$. The dependent variable was the admission RTS with numerical scale. The parameters of RTS are GCS, systolic blood pressure and respiratory rate with the total range from 0-12 (Table 1). There were 31 subjects in this study. The admission RTS and status data of subjects were obtained from the medical records in Dr. Abdul Aziz General Hospital, Singkawang, Indonesia. Intracranial haemorrhage volume data were obtained from the head CT-scan. Data analysis was performed to test the normality and homogeneity followed by the Mann-Whitney U-test. The intracranial haemorrhage volume and outcome (Glasgow Outcome Scale) of the subjects were also analysed with correlation Spearman test to support the result of this study. This study received legal/ethical approval from Dr. Abdul Aziz General Hospital, Singkawang, Indonesia.

\section{Results}

The mean age of the subjects was $31.81 \pm 13.11$ years, the youngest was 11 -year-old and the oldest was 58-year-old. Most of the subject ages were 11-18 years and 35-42 years which were $25.8 \%$ for each. Most of the subjects were male (22 people; 71.0\%). Among the head injury causes traffic accidents were 27 people (87.1\%); downfalls 2 people $(6.4 \%)$ and got punched 2 people $(6.4 \%)$. A total of $51.6 \%$ of the subjects had the greater intracranial haemorrhage volume and most of the subjects were diagnosed as moderate head injury (Table 2).

The mean value of the admission GCS in this study was $10.58 \pm 3.37$, with a range of values from 3 to 15. Majority of the admission GCS values were 7 (mild

\section{Table 2 - Subjects' diagnoses}

\begin{tabular}{lcc}
\hline Diagnoses & Frequency & Percentage (\%) \\
\hline Mild head injury & 9 & 29.0 \\
Moderate head injury & 13 & 42.0 \\
Severe head injury & 9 & 29.0 \\
\hline Total & 31 & 100.0 \\
\hline
\end{tabular}




\section{Table 3 - Surgical intervention and Glasgow Outcome Scale of the subjects (GOS)}

\begin{tabular}{|c|c|c|c|c|c|c|}
\hline Subject & Type of lesion & $\begin{array}{l}\text { Surgical in- } \\
\text { tervention }\end{array}$ & $\begin{array}{l}\text { Indication of surgical } \\
\text { intervention }\end{array}$ & GCS* & RTS* & GOS \\
\hline 1 & $\mathrm{ICH}+$ contusion & craniotomy & $\begin{array}{l}\text { volume of intracranial } \\
\text { haemorrhage }>30 \mathrm{ml}\end{array}$ & 7 & 10 & death \\
\hline 2 & $\begin{array}{l}\mathrm{ICH}+\text { subarachnoid } \\
\text { haemorrhage } \\
+ \text { brain oedema }\end{array}$ & craniotomy & midline shift $>0.5 \mathrm{~cm}$ & 13 & 12 & death \\
\hline 3 & $\begin{array}{l}\mathrm{EDH}+\mathrm{ICH} \\
\text { diastases fracture }\end{array}$ & craniotomy & $\begin{array}{l}\text { volume of intracranial } \\
\text { haemorrhage }>30 \mathrm{ml} \text {; } \\
\text { midline shift }>0.5 \mathrm{~cm}\end{array}$ & 7 & 8 & death \\
\hline 4 & $\begin{array}{l}\mathrm{ICH}+\text { bifrontal } \\
\text { contusion }\end{array}$ & craniotomy & $\begin{array}{l}\text { volume of intracranial } \\
\text { haemorrhage }>30 \mathrm{ml}\end{array}$ & 11 & 11 & death \\
\hline 5 & $\mathrm{EDH}$ & craniotomy & $\begin{array}{l}\text { volume of intracranial } \\
\text { haemorrhage }>30 \mathrm{ml}\end{array}$ & 7 & 10 & $\begin{array}{l}\text { moderate } \\
\text { disability }\end{array}$ \\
\hline 6 & $\begin{array}{l}\mathrm{EDH}+\text { diastases } \\
\text { fracture }\end{array}$ & craniotomy & $\begin{array}{l}\text { volume of intracranial } \\
\text { haemorrhage }>30 \mathrm{ml}\end{array}$ & 11 & 11 & $\begin{array}{l}\text { low } \\
\text { disability }\end{array}$ \\
\hline 7 & $\begin{array}{l}\mathrm{ICH}+\mathrm{SDH} \\
+ \text { contusion } \\
+ \text { brain oedema }\end{array}$ & craniotomy & $\begin{array}{l}\text { volume of intracranial } \\
\text { haemorrhage }=30 \mathrm{ml} \\
\text { midline shift }>0.5 \mathrm{~cm}\end{array}$ & 15 & 12 & $\begin{array}{l}\text { low } \\
\text { disability }\end{array}$ \\
\hline 8 & $\begin{array}{l}\text { bihemisphere } \\
\mathrm{ICH}+\text { contusion }\end{array}$ & craniotomy & $\begin{array}{l}\text { volume of intracranial } \\
\text { haemorrhage }>30 \mathrm{ml}\end{array}$ & 7 & 10 & death \\
\hline 9 & temporal EDH & craniotomy & $\begin{array}{l}\text { volume of intracranial } \\
\text { haemorrhage }>30 \mathrm{ml}\end{array}$ & 10 & 11 & $\begin{array}{l}\text { moderate } \\
\text { disability }\end{array}$ \\
\hline 10 & $\begin{array}{l}\mathrm{ICH}+\text { bifrontal } \\
\text { contusion }+ \\
\text { depressed fracture } \\
\text { of frontal sinus }\end{array}$ & craniotomy & $\begin{array}{l}\text { depressed fracture } \\
>1 \text { tabula; } \\
\text { open fracture }\end{array}$ & 12 & 11 & $\begin{array}{l}\text { low } \\
\text { disability }\end{array}$ \\
\hline 11 & $\mathrm{SDH}$ & craniotomy & $\begin{array}{l}\text { lesion's thickness } \\
>10 \mathrm{~mm}\end{array}$ & 7 & 10 & death \\
\hline
\end{tabular}

GCS - Glasgow Coma Scale; RTS - Revised Trauma Score; ICH - intra-cerebral haemorrhage; EDH - epidural haemorrhage; SDH - subdural haemorrhage; *GCS and RTS of the subjects were evaluated at admission

\section{Table 4 - The outcomes of subjects with conservative treatment}

\begin{tabular}{lccccc}
\hline Revised & \multicolumn{5}{c}{ Glasgow Outcome Scale } \\
\cline { 2 - 6 } $\begin{array}{l}\text { Trauma } \\
\text { Score }\end{array}$ & death & $\begin{array}{c}\text { persistent } \\
\text { vegetative state }\end{array}$ & $\begin{array}{c}\text { severe } \\
\text { disability }\end{array}$ & $\begin{array}{c}\text { moderate } \\
\text { disability }\end{array}$ & $\begin{array}{c}\text { low } \\
\text { disability }\end{array}$ \\
\hline 12 (delayed) & 0 & 0 & 0 & 3 & 4 \\
11 (urgent) & 3 & 1 & 1 & 0 & 4 \\
$3-10$ (immediate) & 1 & 1 & 1 & 0 & 1 \\
\hline Total & 4 & 2 & 2 & 3 & 9 \\
\hline
\end{tabular}


Table 5 - Comparison of Revised Trauma Score (RTS) at admission to the emergency unit to intracranial haemorrhage volume of the subjects

\begin{tabular}{lccr}
\hline $\begin{array}{l}\text { Intracranial haemorrhage } \\
\text { volume/RTS }\end{array}$ & Less volume & Greater volume & Total \\
\hline 12 (delayed) & 8 & 1 & 9 \\
11 (urgent) & 5 & 8 & 13 \\
$3-10$ (immediate) & 2 & 7 & 9 \\
\hline Total & 15 & 16 & 31 \\
\hline
\end{tabular}

coma) and 12 (somnolence) which was $19.4 \%$ for each. The mean systolic blood pressure of the subjects was $116.77 \pm 28.56 \mathrm{~mm} \mathrm{Hg}$, majority of them had $110 \mathrm{~mm} \mathrm{Hg}$ (normal blood pressure). The mean respiratory rate of the subjects was $22.03 \pm 3.45$ times per minute with the most value was 20 times per minute (normal range). The mean value of subjects' RTS at admission to the emergency unit was $10.74 \pm 1.37$ with the most value was 11 (urgent).

There were some subjects in this study who underwent surgical intervention (35.48\%) by a neurosurgeon team (Table 3 ). The outcomes of the subjects were evaluated by the neurosurgeon team where $32.26 \%$ were dead and $38.71 \%$ were alive with low disability among the subjects with surgical intervention and conservative treatment (Tables 3 and 4). In most of the death cases the immediate category of RTS preceded at admission.

Comparative analysis of RTS based on intracranial haemorrhage volume of the subjects was bivariate analysis. This study used statistical analysis MannWhitney $U$-test and showed the value of $p=0.006(p<0.05)$ which meant there was significant difference of RTS at admission to the emergency unit based on intracranial haemorrhage volume (Table 5). The mean of RTS in less intracranial haemorrhage volume was $11.40 \pm 0.74$, while the mean of RTS in greater intracranial haemorrhage volume was $10.13 \pm 1.54$. The intracranial haemorrhage volume had strong correlation $(p=0.000)$ to the outcome of the subjects in this study where the greater intracranial haemorrhage volume had the worse outcome.

\section{Discussion}

Head injury is caused by a collision of the head with another subject, directly or indirectly that may occur abruptly or continuously and by the force of acceleration, deceleration and angulation that can be caused by several aetiologies such as traffic accidents, falls, being hit and so on. Head injury can result in injury to the brain tissue and intracranial haemorrhage such as epidural, subdural, subarachnoid, intracerebral and intra-ventricular. Head injury may affect the physical, physiological, cognitive, emotional and social features of an individual (Rowland and Pedley, 2010; Kumar and Mahapatra, 2012; Abelson-Mitchell, 2013). 
Intracranial haemorrhage by the head injury may lead to secondary brain injury such as space occupying lesion, hypoxia and hemodynamic disturbance which can cause brain damage (Peterson and Scardiglia, 2008; Abelson-Mitchell, 2013; Takahashi et al., 2015). Epidural and intra-cerebral haemorrhage of the volume $\geq 30 \mathrm{ml}$ and subdural haemorrhage $\geq 10 \mathrm{~mm}$ is an indication to evacuation of haemorrhage because it might increase intracranial pressure and become fatal with the herniation of the brain tissue (Sundstrøm et al., 2012; Sherer and Sander, 2014).

Surgical intervention could be undertaken after the evaluation of some variables beside intracranial haemorrhage volume, such as the severity of trauma and prognosis; intracranial pressure; and complications. The indications were evaluated by considering the purpose of surgical intervention in traumatic brain injury, such as to reduce mortality and to improve neurologic outcomes in patients (Carney et al., 2016). In this study, there $35.48 \%$ of the subjects were operated by neurosurgeon team after considering the subjects' conditions, such as intracranial haemorrhage volume, type of lesions, severity of trauma, prognosis and complications. There were two subjects with delayed category of RTS with secondary brain injury, brain oedema, and greater intracranial haemorrhage volume who were operated for decompression of intracranial pressure. But, most of the surgical interventions were done in subjects with immediate category of RTS, low value of RTS, due to the greater intracranial haemorrhage volume to be evacuated and lesion's thickness of subdural haemorrhage $\geq 10 \mathrm{~mm}$. Some of the subjects with low value of RTS were not operated and got conservative treatment
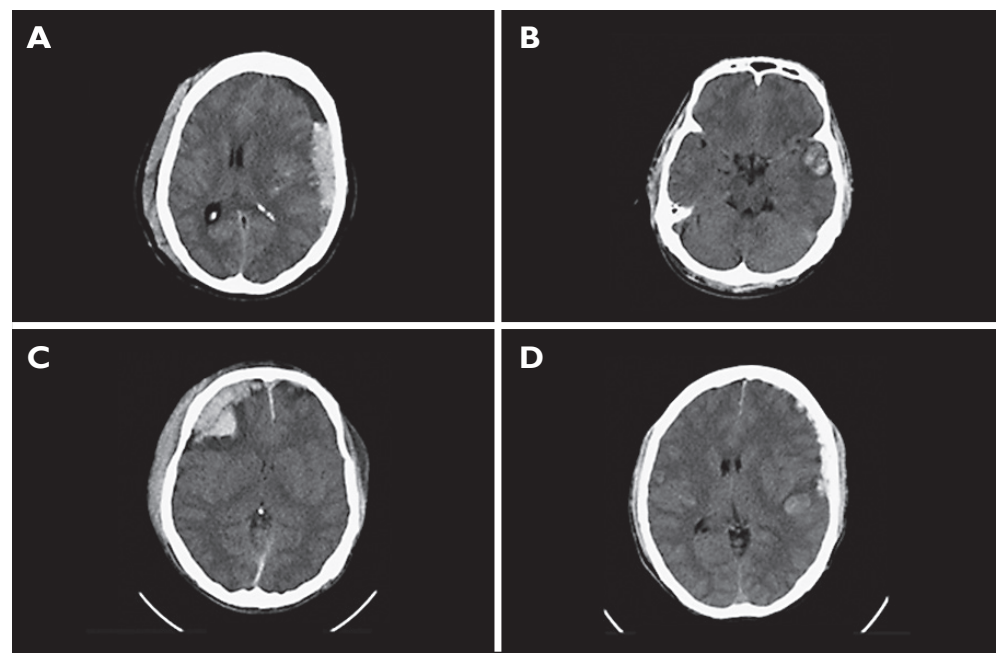

Figure 1 - Subject's head CT-scan section samples (A - female, 53-years-old, RTS 6, greater intracranial haemorrhage volume, outcome: death < 24 hours; $B$ - male, 32-years-old, RTS 12, less intracranial haemorrhage volume, outcome: alive; $C$ - male, 20-years-old, RTS 11, greater intracranial haemorrhage volume, outcome: death in 3 days; $D$ - male, 40-years-old, RTS 11, less intracranial haemorrhage volume, outcome: death in 8 days). 
by considering the purpose and the availability of the subjects to get surgical intervention due to the prognosis.

The result in this study showed that there was a significant difference of RTS at admission to the emergency unit based on intracranial haemorrhage volume. The result indicates conformity with the theory. The higher RTS value indicates a better physiological state. So the less was the intracranial haemorrhage volume, the better patient's physiological state with higher RTS. While the greater intracranial haemorrhage volume was, the worse was the patient's physiological state with lower RTS. In statistical analysing, this study also showed that there was a strong correlation between intracranial haemorrhage volume and outcome of the subjects where the greater intracranial haemorrhage volume was followed by the worse outcome. This result might support the use of RTS in clinical practice, especially in traumatic cases such as head injury.

Brain injury as a result of intracranial haemorrhage can cause cortical and subcortical damage which can cause disruption of the autonomic nervous system which is important to physiological functions such as the regulation of breathing, blood pressure, and the complex system of consciousness (Sherer and Sander, 2014; Takahashi et al., 2015). Hypothalamus has an important role in controlling the autonomic nervous system. Hypothalamus receives input from the cortex and transmits the signals to the brain stem and spinal cord as autonomic nerve signals which are transmitted to the peripheral nervous system and organs. Injury to the brain tissue can disrupt the system. Disruption of hemodynamic and intracranial pressure can cause secondary brain injury and may affect the hypothalamus in its role of producing catecholamine locally or systemically and the regulation of parasympathetic system which may disrupts blood pressure and respiratory system. Thus, a head injury with intracranial haemorrhage may impair the blood pressure, respiratory rate and consciousness (Martins et al., 2009; American College of Surgeons, 2012; Berry et al., 2012; Lee and Rincon, 2012; Takahashi et al., 2015).

That physiological state can be assessed objectively by RTS with the assessment of GCS, systolic blood pressure and respiratory rate, which are regulated by the autonomic nervous system that may be affected by intracranial haemorrhage volume of head injury (Alqarni et al., 2011; Orhon et al., 2014; Mohyuddin et al., 2015; Takahashi et al., 2015).

As showed in Figure 1, majority of subjects in this study had the lower RTS at admission to the emergency unit with the greater intracranial haemorrhage volume and the higher RTS with less intracranial haemorrhage volume as the patients A and B. The significancy had been proofed by statistical analysis. However, in some subjects, e.g. patient C, RTS at admission could not always predict the intracranial haemorrhage volume. In the case of patient C, the RTS was quite high (RTS 11, urgent), but the head CT-scan showed the greater intracranial haemorrhage volume. Those conditions could happened due to several factors such as the 
time of RTS evaluation, location of intracranial haemorrhage, age of the subjects, complications and other internal and external factors that may influence the physiological condition of the subjects. In this study, we could not control the time of RTS evaluation from the injury variable. The serial evaluation should be held in any emergency cases such as head injury to monitor the current condition and complications such as cerebral oedema, herniation and any deteroriation of the patient. In some cases, a patient may have the higher RTS at admission and less intracranial haemorrhage volume but with a poor outcome (patient D). As much as $32.26 \%$ of the subjects were dead and the others were alive with persistent vegetative state and disability. The outcomes were evaluated by the neurosurgeon team with Glasgow Outcome Scale. There was a subject with high RTS value (RTS 12 , delayed) at admission and with less intracranial haemorrhage volume at early head CT-scan examination but the following outcome was poor, death, due to brain oedema as the complication of brain injury which increased the intracranial pressure and resulted in herniation.

\section{Conclusion}

There was significant difference of RTS at admission to the emergency unit based on intracranial haemorrhage volume among head injury patients. The greater intracranial haemorrhage volume was accompanied with lower RTS value which means more detrimental physiological condition.

Acknowledgements: The authors thank to Dr. Abdul Aziz General Hospital, Singkawang, Indonesia, so this research can proceed.

\section{References}

Abelson-Mitchell, N. (2013) Neurotrauma: Managing Patients with Head Injury. John Wiley and Sons, Oxford. Alqarni, M., Arabi, Y., Kakiashvili, T., Khedr, M., Koczkodaj, W., Leszek, J., Przelaskowski, A., Rutkowski, K. (2011) Improving the predictability of ICU illness severity scales. Proceedings of the Federated Conference on Computer Science and Information Systems (FedCSIS), Szczecin, Poland, 2011.

American College of Surgeons (2012) Advanced Trauma Life Support: Student Course Manual, $9^{\text {th }}$ Ed. American College of Surgeons, Chicago.

Badan Pusat Statistik Provinsi Kalimantan Barat (2015) Kalimantan Barat in Figures 2015. BPS Provinsi Kalimantan Barat, Pontianak.

Berry, C., Ley, E. J., Bukur, M., Malinoski, D., Margulies, D. R., Mirocha, J., Salim, A. (2012) Redefining hypotension in traumatic brain injury. Injury 43, 1833-1837.

Broderick, J., Connolly, S., Feldmann, E., Hanley, D., Kase, C., Krieger, D., Mayberg, M., Morgenstern, L., Ogilvy, C. S., Vespa, P., Zuccarello, M. (2007) Guidelines for the management of spontaneous intracerebral hemorrhage in adults: 2007 update: A guideline from the American Heart Association/American Stroke Association Stroke Council, High Blood Pressure Research Council, and the Quality of Care and Outcomes in Research Interdisciplinary Working group. Stroke 38, 2001-2023.

Carney, N., Totten, A. M., O’Reilly, C., Ullman, J. S., Hawryluk, G.W. J., Bell, M. J., Bratton, S. L., Chesnut, R., Harris, O. A., Kissoon, N., Rubiano, A. M., Shutter, L., Tasker, R. C., Vavilala, M. S., Wilberger, J., 
60) Prague Medical Report / Vol. 119 (2018) No. 1, p. 52-60

Wright, D.W., Ghajar, J. (2016) Guidelines for the management of severe traumatic brain injury, fourth edition. Neurosurgery 80, 6-15.

Elliott, J., Smith, M. (2010) The acute management of intracerebral hemorrhage: a clinical review. Anesth. Analg. 110(5), 1419-1427.

Faul, M., Xu, L., Wald, M. M., Coronado, V. G. (2010) Traumatic Brain Injury in the United States: Emergency Department Visits, Hospitalizations, and Deaths. Centers for Disease Control and Prevention, Atlanta.

Kumar, R., Mahapatra, A. K. (2012) A Textbook of Head Injury, $1^{\text {st }}$ Ed. JP Medical Ltd., New Delhi.

Lee, K., Rincon, F. (2012) Pulmonary complications in patients with severe brain injury. Crit. Care Res. Pract. 2012, 207247.

Martins, E. T., Linhares, M. N., Sousa, D. S., Schroeder, H. K., Meinerz, J., Rigo, L. A., Bertotti, M. M., Gullo, J., Hohl, A., Dal-Pizzol, F., Walz, R. (2009) Mortality in severe traumatic brain injury: a multivariated analysis of 748 Brazilian patients from Florianópolis City.J. Trauma 67(1), 85-90.

Mohyuddin, G. R., Alam, Z., Malik, U. Z., Shakil, O., Haq, A. (2015) Revised Trauma Score as a predictor of outcome in trauma cases: Experiences at a tertiary care hospital in Karachi, Pakistan. J. Ayub Med. Coll. Abbottabad 27(3), 584-586.

Orhon, R., Eren, Ș. H., Karadayı, Ș., Korkmaz, I., Coskun, A., Eren, M., Katrancıoğlu, N. (2014) Comparison of trauma scores for predicting mortality and morbidity on trauma patients. Ulus. Travma Acil Cerrahi Derg. 20(4), 258-264.

Peterson, N., Scardiglia, J. (2008) Advanced Trauma Life Support for Doctors: ATLS Student Course Manual, $18^{\text {th }}$ Ed. American College Surgeons, Chicago.

Riyadina, W., Suhardi, Permana, M. (2009) Pola dan determinan sosiodemografi cedera akibat kecelakaan lalu lintas di Indonesia. Maj. Kedokt. Indon. 59(10), 464-472.

Rowland, L. P., Pedley, T.A. (2010) Merritt's Neurology, $12^{\text {th }}$ Ed. Lippincott Williams and Wilkins, Philadelphia. Sherer, M., Sander, A. M. (2014) Handbook on the Neuropsychology of Traumatic Brain Injury. Springer, New York. Sundstrøm, T., Grände, P. O., Juul, N., Kock-Jensen, C., Romner, B., Wester, K. (2012) Management of Severe Traumatic Brain Injury: Evidence, Tricks, and Pitfalls. Springer Science and Business Media, Heidelberg.

Takahashi, C., Hinson, H., Bagulay, I. J. (2015) Autonomic Dysfunction Syndromes after Acute Brain Injury, $3^{\text {rd }}$ Ed. Elsevier, Philadelphia. 